\title{
Study on the Legality of Right to Decide Human Organ Transplantation in China
}

\author{
Wenyi Qi* \\ School of Humanities and Law, Northeastern University \\ Shenyang, China
}

\begin{abstract}
Human organ transplantation is an important symbol of medical development to improve the survival rate of some patients. However, the supply and demand of human organ transplantation is not balanced in China. This paper focuses on exploring the legislation on human organ transplantation to adapt to the current situation of organ transplantation in China. The paper discusses about the nature of human organ transplantation, the decisive object of human organ transplantation, the decisive subject of human organ transplantation, and refers to the systems of other countries and regions to seek the legal improvement of the decision-making power of human organ transplantation in China. The paper shows that legislators should relax the scope of organ transplantation within the legal framework, such as expanding civil capacity limitation, so as to improve the relevant legislation on human organ transplantation and promote the rapid development of human organ transplantation.
\end{abstract}

Keywords-Human organs; Transplantation; The decisionmaking power; Legitimacy

\section{INTRODUCTION}

Human organ transplantation is a comprehensive issue concerning law, medical treatment and ethics. At present, the technology of human organ transplantation is becoming more and more perfect, but the supply and demand of human organs are extremely unbalanced. The World Health Organization (WHO) study shows that the ratio of organ supply to demand in the world is about 1:25 on average, and the ratio in China is even more worrying. Therefore, a series of problems have arisen, such as illegal removal of living organs, ineffective allocate, such as illegal removal of living organs, ineffective allocation of donor resources, the tendency to commercialize organs, improper use of cadaver organs of condemned criminals, and many other legal issues, In order to solve these problems better, the author will use the method of comparison from the aspects of the nature of human organs, the subject of human organs determination, the object of human organs determination, to put forward the legislative improvement suggestions of the decision-making power of human organ transplantation in our country at present, expand the scope of donors, and standardize the operation of human organ transplantation, and realize its legalization and rationalization.

\author{
Tianchong Yao \\ Professor of Northeastern University \& Legal adviser of the \\ Liaoning provincial government \\ School of Humanities and Law, Northeastern University \\ Shenyang, China
}

\section{SUMMARY OF HUMAN ORGAN TRANSPLANTATION}

\section{A. Concept of human organ transplantation}

Human organ transplantation has always been an intertwined field of medicine and law. Human organ transplantation refers to the treatment of transplanting healthy organs from the human body (living or non-living) into the recipient's body in order to replace the organs which can not fully realize their functions due to disease or injury.

\section{B. Concept of transplanted organs}

\section{1) Range of human transplant organs}

Human Organ Used for Transplantation refers to the process of removing the organ from the donor and implanting it into the recipient's body to replace the organ damaged by the disease. The broad definition of human transplant includes tissue such as bone marrow and blood.

According to Article 2 of the Ordinance on Human Organ Transplantation of China, the term "human organ" in this Ordinance refers to the whole or part of the heart, lung, liver, kidney or pancreas and other organs of a human organ donor with specific functions. This Ordinance shows that the human organ transplantation stipulated in our legislation is a narrow definition. Meaning, human cells, corneas, bone marrow and other human tissues, do not belong to the category of organs, in the following we are discussing the narrow sense of human organ transplantation.

\section{2) Properties of transplanted organs}

From the perspective of civil law, human body has special attributes and is the carrier of personality [5]. It cannot be regarded as material. Human transplant organs belonging to human body are the material form of civil subjects. Therefore, living human organs and tissues cannot be treated as objects without separation from the human body. In academia, the debate on human organ transplantation mainly focuses on the issue of organ properties that are separated from the human body, and the academic circle mainly has the following theories [2]:

Firstly, the attribute of the substance. According to the German scholar Medicus [4], the human organ that can be used for transplantation is the object, which is the possession of the 
living person. Like the movable property, it has the fluidity of the object, that is, the organ can be bought and sold.

Secondly, limited personality attribute. In order to protect the integrity of the human body, under certain conditions, the organs separated from the living body are still regarded as human body. Since the purpose of organ transplantation is still reimplantation, if these body parts are separated from the human body, the purpose is to connect them with the body after the fact according to the intention of the person entitled to the body, in order to achieve the purpose of protecting the normal function of the body, to commit a fault tort in another person and cause these. From one part of the body right is damaged, the purpose of human rights cannot be realized, the integrity of the person is not guaranteed. Therefore, the infringer shall be liable for damages according to the right to infringe upon the integrity of others [6].

Thirdly, Dual attributes. The organs and tissues out of body does not belong to the attribute of the substance, the nature of the rights call organ rights, the rights to body spanning the two fields of personal rights and property rights. Namely, in the outside world for an organ and human rights from organ to organ rights, for out of the organs, enjoy the real right. The organ right which is not separated from the body is the personal right in the living body and the property right in the dead body. The organ right which has been separated from the body is in the living body and the corpse is the property right.

Although there is no regulation on the nature of organs in Chinese law, most scholars think that things that are separated from human body have the properties of objects. But for such contracts, creditors have no right to request enforcement. ${ }^{1}$

The author agrees with the third points. Organs belong to the human body, so that they cannot be regarded as the object of rights, at this time the organ is personality; and in the process of transplantation, the organ will stay away from the human body in a short time or a longer period, at this time it has the nature of matter. It is precisely because the organ belongs to the human body that it is disposable, at this time also has the property of things, and it is precisely because of this disposition that makes living organ transplantation possible.

\footnotetext{
${ }^{1}$ According to article 128 (2) of the draft Chinese civil code proposed by Liming Wang, the organs, blood, bone marrow, tissues, sperm and eggs of natural persons can be used as objects without the limit of public order and good customs.

Huixing Liang believed that the human body is not an object of rights. One part of the body, once separated from the person, should be regarded as an object.

The Taiwanese scholar Shangkuan Liang holds that when one part of the person is naturally separated from the body, it is no longer a person, but an external object, certainly a legal object and the object of the right. And the original ownership of the part which belongs to the person who belongs before the separation may be managed according to the intention of the right holder.
}

\section{ThE DECISIVE OBJECT OF HUAMAN ORGAN TRANSPLATATION}

\section{A. The source of the object of human organ transplantation}

A human organ transplant donor (hereinafter referred to as the donor) is a living or cadaver that provides organs to a recipient (hereinafter referred to as the recipient) during a medical procedure. Organ transplant donors mainly come from:

\section{1) Non-living donors}

The donation of human remains refers to the act in which a natural person voluntarily gives all or part of his or her remains to the cause of medical science after death. The act of donating all or part of the remains of a natural person to the cause of medical science after the death of a person who has not expressed his intention to donate. Or the remains of executed criminals.

\section{2) Living donors}

According to the Ordinance on Human Organ Transplantation of China, the recipients of living organs in China are limited of living organ donors, to the spouses, lineal relatives or collateral relatives by blood within three generations, or those who have evidence to prove the existence of a family relationship with living organ donors because of help. In addition, living organ donation is not allowed. At the same time, it should be noted that the organs provided by living donors are limited, and the law does not permit the saving of one person on the premise of sacrificing the lives of another innocent person. Therefore, the organs provided by living donors should be paired and renewable, that is, they should not affect the life and health of the donor.

\section{3) Bonor with brain death}

In the field of organ transplantation, some countries with rich practice of organ transplantation, such as Japan, brain death is the basis for determining the death of donors, China can gradually lead brain death in practice, as the criteria for determining the death of donors. Brain death donor refers to the patient who is diagnosed as irreversible loss of brain function and provides organs for the recipients of human organ transplantation with the consent of his relatives.

\section{THE DECISIVE SUBJECT OF HUAMAN ORGAN TRANSPLATATION}

Human organ transplantation, as mentioned earlier, may be either living or non-living (cadaveric), so that the decisionmaking body of human organ transplantation has the possibility of separating from the donor.

\section{A. Donors for transplanted organs}

The most direct and indisputable subject of the decisionmaking power of human organ transplantation is the donor's own decision-making power. 


\section{1) Scope of decision-making power of donors}

a) Living organ transplantation

The organ that is not separated from the human body is a part of the human body, a biological carrier of the right of personality, and an indivisible part to maintain the integrity of the human body. The owner of the organ should undoubtedly be the civil subject who enjoys the right of personality. Therefore, whether organs and tissues are willing to be separated from their bodies, and whether they are willing to be donated, should be decided by the civil subjects of human organs or tissues, that is, the right of the person entitled to the body to separate and donate human organs or tissues.

\section{b) Predetermined non-living organ donation}

Such non-living organ donation is a valid reservation made while the individual is still alive. If the donor completes the donation agreement or makes a will before his death, he can transplant the organ after his death, and when the donor regrets or is unwilling for other reasons. When organ donation is made, it should be allowed to change and cancel the donation, and it has the right to choose to give up donation.

\section{2) Conditions for decision-making power of the donor}

Because living organ transplantation has a significant impact on the donor's own living health, organs are located in the human body, but as previously analyzed organs in the living body are not pure substance, so the exercise of the decision-making power of transplantation also has certain requirements. From the perspective of comparative law, the author will analyze the legality and rationality of limiting the following elements.

\section{a) Age limit}

According to the Ordinance on Human Organ Transplantation of China, it requires donors to have full capacity for civil conduct and over 18 years old. According to the General Principles of Civil Law, citizens over the age of 16 and under the age of 18 whose main source of livelihood is their own labor income are regarded as persons with full capacity for civil conduct, indicating that the judgement of the General People's Congress on the complete capacity for civil conduct does not rely solely on the age limit, but on the ability to identify the requirements. However, the Ordinance on Human Organ Transplantation of China, clearly prohibits the removal of living organs from citizens under the age of 18 for transplantation, which is undoubtedly in contradiction with the Superior Law.

According to the German Organ Transplant Act, organ donors must have the ability to agree. The judgement of consent depends on the ability to identify, and the consent to donate is also required. It can be seen that the German law does not limit the age of the donor. The author tends to be limited to allow minors to organ donation [3].

\section{b) Mental health}

The donor can only be with full capacity for civil conduct, but excludes the person without capacity for civil conduct and the person with limited capacity, and directly denies the decision ability or consent ability of the person without capacity for civil conduct and the person with limited capacity. As for the subject of organ donation, it is theoretically understood that the subject of organ donation can only be a person with full civil capacity.

In this regard, the author thinks that there can be exceptions for some special groups. On the basis of protecting the rights and interests of donors, the state can make exceptions for some special donors, so as to expand the source of organs and save more lives. For adult mental patients, Macao regulations, that is to remove the organs and tissues of adult mental patients, must be allowed by the court, and I must not object. And the intermittent psychiatric patient, whose ideographic behavior under normal circumstances, is real and effective. At this time, if it makes the intention to donate organs, should be recognized.

\section{B. Close relatives of donors}

There are some disputes about whether close relatives can decide the organ donation. The author agrees that close relatives can be used as the main body of organ donation, which is also the consensus of the legal profession.

\section{1) Scope of decision-making power of close relatives}

For living organ transplants, throughout the laws of various countries, regardless of whether the donor has civil capacity, his relatives may not control the living organs or have the right to decide. The decision-making power of donor relatives is mainly limited to non-living organ transplants, including organs or dead organs.

At the same time, the decision-making power of close relatives includes the right to consent, including the right to deny. In some countries, only relatives have the right to decide whether to donate the organs of the deceased. Even if the deceased agreed to donate during his lifetime, if the relatives do not agree, the will of the deceased Will be considered invalid [1].

\section{2) Conditions for decision-making power of close relatives}

Firstly, without explicit denial of the dead.

Secondly, the scope of person who has the right to agree: spouses, adult children and parents.

Thirdly, Common consent. The intention of organ donation must be expressed in writing by all close relatives. In this way, the provisions can avoid disputes between close relatives because they cannot reach a consensus, and fully respect the decision-making power of each close relatives.

Fourthly, Capacity for civil rights. Only natural persons with full civil capacity can decide the penalty for donation of the deceased's cadaver organs. 


\section{B. State agency}

\section{1) Scope of decision-making power of state agency}

As a special decision subject, the state organs can only decide to limit the death penalty to those who meet the conditions stipulated by law. Although the number of condemned criminals themselves is small and limited, but the condemned criminals do occupy the majority in medical practice, is an important source of human organ transplantation.

\section{2) Conditions for decision-making power of state agency}

Firstly, without explicit denial of the dead.

Secondly, the body of condemned criminal is not taken over. In 1984, the Supreme People's Court and five other state organs issued the Provisional Provisions on the Use of the Corpses or Organs of condemned criminal. Article 3 provides for the availability of types of cadavers or organs of condemned criminal: no one or his family refuses to do so; and It can be learned that the death penalty prisoners in the absence of convergence or family members refuse to converge, in accordance with the relevant provisions of Article 4 of the Regulations to determine the condemned criminal organ transplantation.

\section{LEGISLATIVE PROPOSALS FOR IMPROBING THE DECISION-MAKING POWER OF ORGAN TRANSPLANTATION IN CHINA}

\section{A. Promote the legislation of donors with brain death}

About the death standard, Chinese law adopts the comprehensive standard theory at present, namely spontaneous respiratory arrest, cardiac arrest, pupil reflex function stop. But in the international community, many countries regard death as brain death, because although brain death still has heartbeat, but it has no consciousness, and its death is irreversible. The difference in the standard of death also leads to the difference between the brain death donor and corpse donor. Brain-dead donors can have a beating heart, so long as the artificial ventilator is not shut down, their organs and cells will not be biologically dead, can be repeatedly extracted fresh organs for transplantation use; and ordinary donors breathing and heartbeat has been completely stopped, if the donor is not specially handled, the organ can only be removed once [4]. Once the donor has entered the biological death period, the organ can no longer be used for transplantation. Moreover, the application of non-living donor organs is technically demanding, and the risk is increasing, and the operation time is demanding. Therefore, the difficulty of obtaining organ transplantation from ordinary dead is much higher than that from brain-dead donors.

Therefore, to promote the legislation of brain-dead donors will be helpful to the behavior of human organ transplantation in the medical field, make up for its blank, and realize the standardization and legalization of brain-dead donors.

\section{B. Enlarge civil capacity limitation}

Article 8 of the Ordinance on Human Organ Transplantation of China stipulates clearly that the donors are limited to persons with full capacity for civil conduct. Strict conditions are applied to the qualifications of donors, and there are no exceptions for minors and psychotic patients.

In this regard, the author thinks that exceptions can be made for some special groups. For example, the restrictions on minors can be relaxed to the extent that they have complete cognitive and consent abilities, instead of strictly requiring 18 years of age. Intermittent psychiatric patients, though limited in their capacity to act, should also have the right to decide organ transplantation in a waking state. On the basis of protecting the rights and interests of donors, the state can make exceptions to some special donors, so as to expand the sources of organs and save more lives in urgent need of organ transplantation.

\section{Standardize and clear the use of organ transplantation belongs to condemned criminal}

Due to cultural, conceptual and ethical factors, less than $5 \%$ of living donors in organ transplantation in China are cadavers, and more than $95 \%$ of these donors are cadavers, the vast majority of which come from condemned criminals. At present, only the Provisional Provisions on the Use of the Corpses or Organs of condemned criminal has become the only judicial document regulating the source of organ donors of condemned criminal offenders. The old provisions will inevitably produce a series of new problems. At the same time, due to the particularity of the condemned criminals, the reform of the law for the protection of the rights of the condemned criminals is still insufficient, resulting in a lot of organ transplantation contrary to the hospital phenomenon. In addition to the implementation of relevant supervision needs more external supervision, a large number of operations need to get rid of some "opaque" state, the legislature should also keep pace with the times, solve the corresponding problems, and protect the rights of condemned criminals.

\section{CONCLUSION}

At present, the subject of human organ transplantation decision-making power in China has individual donors, close relatives of donors and state organs under limited conditions. At the same time, the object of decision-making is mainly living organs and non-living organs with restricted conditions. However, due to the special cultural and ethical factors in China, the resources of organ transplantation in China are very few and the supply and demand are extremely unbalanced, which requires legislators to relax the scope of organ transplantation within the legal framework, such as enlarging of civil capacity limitation, promoting the legislation of brain death donors, standardizing and clearing the use of organ transplantation belongs to condemned criminal. In this way, to promote the standardization of organ transplantation and save more people's lives and realize the greatest social value of law. 


\section{REFERENCES}

[1] Li Pei. Research on the main body of human organ donation contract [D] Tianjin Commercial University, 2014. (In Chinese)

[2] Wu Yingxiong, Tian Kan. Discussion on the Legal Attribute and Right Attribution of Human Organs[J].China Health Management, 2012,29(03): 202-203+215. (In Chinese)

[3] Li Ningyan. Comparative study of organ transplantation legislation between China and Germany [D]. Nanchang University, 2014. (In Chinese)

[4] Yan Zhiwei. Legal research on donor of human organ transplant [J]. Hebei law, 2008 (08): 89-92+98.

[5] Zou Weiqiang. Civil law on invalid living organ transplantation [J]. law forum, 2014,29 (04): 86-92. (In Chinese)

[6] General introduction of German civil law [M]. Law Publishing House, (Germany) Dieter Medicus (Dieter Medicus), 2000. 